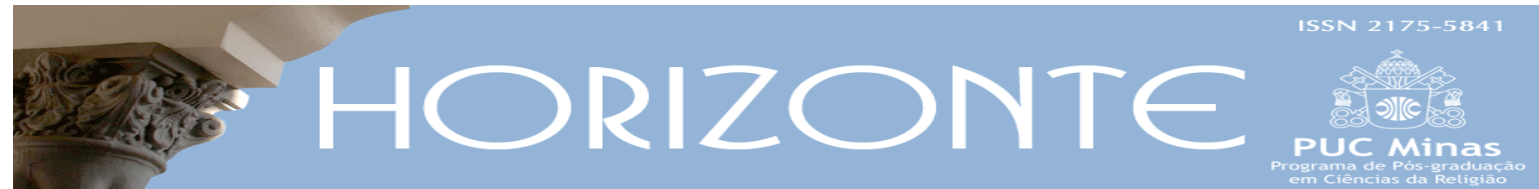

Dossiê: Teorias de linguagem e Estudos de Religião - Artigo Original ๑용

\title{
Contribuição da teoria de Bakhtin ao estudo das linguagens da religião
}

\author{
The contribution of Bakhtin's Theory for the study of the languages of \\ religion
}

Antonio Carlos de Melo Magalhães*

\begin{abstract}
Resumo
O artigo, em diálogo com conceitos da teoria de Bakhtin, propõe uma leitura da religião como infinitude de possibilidades. Ao recorrer aos conceitos de dialogismo, polifonia e não-finalizibilidade, o artigo estabelece uma crítica a teorias reducionistas das linguagens da religião. A perspectiva advinda da teoria bakhtiniana abre horizontes para leituras das linguagens da religião que destacam o caos-mundo como lugar das experiências religiosas, caracterizadas pela inventividade (poiésis) e eventividade (situacionalidade), originando singularidades nas linguagens da religião nem sempre contempladas por teorias mais reducionistas. Dialogismo como teoria da cultura e filosofia da vida, polifonia como teoria do romance das personagens de Dostoiévski e não-finalizibilidade como teoria da história formam o referencial teórico de uma interpretação que entende as linguagens da religião em seus processos, devires e bricolagens.
\end{abstract}

Palavras-chaves: Bakhtin; dialogismo; religião; linguagem.

\begin{abstract}
The article proposes in dialogue with the Bakhtin's theory an interpretation of the religion as infinity of possibilities. The concepts of dialogism, polyphony and unfinalibility criticize the reducionistic theories of the languages of religion. The perspective based on the Bakhtin's theory opens horizon meaning for interpretation of languages of religion that inhabit the chaos-world as place of religious experiences which characteristics are the poiesis and the concrete situations, that originate the singularities in the languages of religions. Dialogism as a theory of culture and as a philosophy of life, polyphony as theory of novels and unfinalibility as a theory of history constitute the theoretical approach of an interpretation of languages of religion in their processes, future making and cultural transformation.
\end{abstract}

Keywords: Bakhtin; dialogism; religion; language.

Artigo submetido em 22 de setembro de 2018 e aprovado em 07 de novembro de 2018.

* Doutor em Teologia - Universität Hamburg (1991). Pós-Doutor em Literatura pela Universidade Federal de Santa Catarina (2015) e pela Universität Hamburg (2018). Professor da Universidade Estadual da Paraíba. País de origem: Brasil. E-mail: magalhaes.uepb@gmail.com 


\section{Introdução: das coisas (quase) óbvias}

“A religião vem sendo muito mal tratada", uma expressão que ouvi recentemente de interlocutor que falava sobre o trato (indevido) dispensado por alguns estudos nas ciências da religião ao seu objeto de pesquisa. Eu complementei, opinando que não é diferente do trato dado por estudiosos de outros centros que não os de ciências da religião. O que nos une na crítica é a reiterada constatação de que religião é tomada como um objeto que confirma outras realidades da vida humana, sendo parte da conceituação uma forma de celebrar sua penúria e o lugar de sua desgraça, sem esquecer que, dependendo de quem opera o conceito, a religião também pode ser usada para festejar as revoluções e anunciar as rebeldias. Nessa linha, religião tornar-se-ia a comprovação da injustiça social, a vontade reprimida, a vontade de poder mal articulada, um lugar a mais das alienações na sociedade, ou no pensamento mais à esquerda, a religião seria a força para a vitória dos oprimidos. Parte da carga conceitual é moderna, essa máquina de considerar as linguagens passadas como ultrapassadas ou de fazer os passados narrativos falarem e confirmarem as revoltas críticas sob o signo da modernidade pretensamente emancipada e autônoma.

As ciências sociais são expressão contundente desse tipo de abordagem, mas outros campos também foram tomados por esse "ateísmo metodológico" típico de uma abordagem que sempre vaticina a religião como atraso, infantilidade, deturpação e obscuridade; sem esquecer que alguns estudos da religião são tomados por um revoar de anjos paladinos das justiças para o mundo, nessa aparente contramão da modernidade, quando na verdade é só uma face dela, porque necessita tornar as experiências diversas, complexas, contraditórias um tanto uniformes, lineares e máquinas reprodutivas eficientes. Tais abordagens determinam os resultados que se prestam a construir as comunidades de consenso, numa assepsia moderna-crítica. Antes mesmo que os temas, os grupos e os lugares concretos sejam apresentados, de certa forma já sabemos onde isso vai dar no jogo das ciências da religião e em outros observatórios reguladores do bem-estar espiritual da sociedade: religião, só aquela que passou pelo crivo do que ela tem 
que ser em sua penúria e em seu atraso - para mostrar quão alienada ela é - ou a que deveria ser - para fazer mover os humanos em torno de lutas ideológicas quaisquer por mundos novos. Parte do jogo desse tipo de ciência é saber previamente os resultados e tornar seu "campo" ou "objeto" o lugar da comprovação que precisa ser reificada para assegurar o lugar da ciência, a única sobrevivente, no final das contas, que importa. Religião está maltratada não pelos seus algozes, mas pelos seus estudiosos, por aqueles que fizeram da religião seu tema, seu objeto, sua trajetória intelectual.

Essas coisas óbvias poderiam ser o nosso ponto de partida, mas presumo que esse estado atual da questão ainda seja o ponto de chegada de alguns estudos. Zonas de deserto de criatividade intelectual e casarões habitados de um dogmatismo travestido de higiene conceitual.

Naquilo que me proponho no presente artigo há uma tentativa de distanciamento dessa forma de elaborar os estudos da religião. A estratégia é de buscar em horizontes teóricos normalmente não assimilados pelas ciências da religião a possibilidade de elaborar diálogos e aproximações com as linguagens da religião. Nesse sentido é que o diálogo com Bakhtin se apresenta como uma possibilidade de romper tanto com uma tradição exegética instaurada numa compreensão restritiva de texto quanto com uma tradição dos significados já previamente decididos pelo "totalitarismo teórico" seja da teologia, seja das ciências sociais, seja de outras áreas.

Os modelos de estudos da religião garantem mais ou menos a significação de qualquer coisa que se possa descobrir. Só descobrimos o que já sabemos, mas religião é inventividade (poiésis) e eventividade (situacionalidade) e constitui um arco de possibilidades incômodas e, algumas vezes, surpreendentes. Religião é a linguagem mais radical da infinitude das possibilidades humanas em seus devires.

As linguagens da religião (as linguagens humanas gesto, imagem-metáfora, narrativa, correspondendo a rito, ícone-poesia, mito, segundo Nogueira (2016), agregam continuamente, mas também desagregam, geram modificações naquilo 
que foi reunido, criando uma cadeia de experiências e narrativas não-finalizadas e não-finalizáveis, algo importante para a teoria bakhtiniana da não-finalizibilidade da história. O melhor projeto da linguagem é como a própria dimensão biológica do humano: um projeto imperfeito. Desordem e conserto são as características, não a adaptação perfeita, não a ordem. O caos-mundo (GUATTARI, 1992) é o mundo da religião.

\section{Os conceitos}

Trabalho com três conceitos de Bakhtin: Não-finalizibilidade, Polifonia e Dialogismo, e digo de forma resumida possíveis significações. Não-finalizibilidade eu compreendo como chave de uma teoria da história em Bakhtin, em rejeição a uma visão hegeliana - não há ápice da história em Bakhtin - ou mesmo marxista da história, naquilo que ela apresenta de dialética mecanicista, sem conceder direitos a uma "filosofia burguesa" em seu individualismo estéril. A não-finalizibilidade é o conceito que mostra um Bakhtin na fronteira das grandes teorias da história de seu tempo. A história nunca está encerrada, há um jogo a mais, há possibilidades abertas.

Polifonia é claramente uma teoria do romance, impulsionada pela literatura de Dostoiévski, com personagens plenivalentes e imiscíveis. Dialogismo se apresenta, por sua vez, como teoria da cultura e filosofia de vida, cujos processos dialógicos rompem com os monologismos e com uma dialética que determinaria o diálogo simplesmente a partir de ações pre-vistas.

Para Bakhtin, grande parte do empenho teórico se dá nas interpretações que ele faz acerca da literatura, de sua constituição. A relação da literatura com o “extra-linguístico" pressupõe tanto a dimensão profundamente dialógica da vida quanto a dimensão sígnica da psiquê humana, sendo a concretização da consciência essa relação entre o eu - sempre pensado em suas tessituras coletivas e os outros no fazer cultural e ideológico do cotidiano. Para Bakhtin, não existem, portanto, rupturas entre o interior e o exterior, antes o que existe é o processo constante e unificado, mas nunca uniforme e repetitivo. Não existe, por 
conseguinte, uma vida interior que não se plasme num signo, daí que a consciência é sempre um dado social e cultural. Além disso, o que temos em Bakhtin é uma compreensão da mudança linguística não somente em seu ordenamento sistêmico, mas desordenada, produzida por eventos imprevisíveis da atividade cotidiana. A mudança linguística não resulta de abstrações, mas de ações de pessoas reais em seus fazeres cotidianos. O povo é um inventa-línguas, no dizer de Haroldo de Campos. Isso porque as palavras e as formas existem em nós assim como existem no mundo social, como impulsos vivos marcados por memória, atividade, diálogo, confusão. A linguagem, em seu uso cotidiano e na obra de arte, é efetivamente constituída por forças extralinguísticas, porque o discurso é sempre dialógico, e o dialogismo não pode ser reduzido a quaisquer categorias linguísticas formais. $\mathrm{O}$ dialogismo nasce e se desenvolve na vida, continua na arte, se traduz nas culturas, habita a própria ideologia e até mesmo os monólogos indicam processos dialógicos do sujeito que pensa a si mesmo. O si-mesmo é sempre um para-si, permanentemente interpelado pelo fora-de-si (fulano está fora-de-si - sempre estamos fora-de-nós).

Uma crescente constatação em textos recentes de estudiosos da obra de Bakhtin no Brasil é da urgência de (re) descobrirmos sua obra e de sermos menos dependentes dos comentadores franceses. O uso um tanto rápido e consensual demais que tem sido feito em monografias, artigos, dissertações e teses, reduzindo ou confundindo dialogismo a teorias da intertextualidade ou interdiscursividade nos conduz a uma nova busca por matizes da teoria de Bakhtin. Além disso, não podemos deixar de negar a confusão entre dialogismo - uma filosofia da vida e uma teoria da cultura - e diálogo - uma interlocução entre sujeitos. Constata-se uma exagerada dependência de Kristeva e a forma como ela estabeleceu a mediação das obras de Bakhtin no contexto da França, que se prolongou a outros contextos acadêmicos; a comunidade acadêmica brasileira, por muito tempo, refletiu mais as teses de Kristeva do que as de Bakhtin, processo em parte superado pela contribuição que os estudos bakhtinianos têm realizado em nosso contexto (a título de exemplos: Bezerra (2011), Brait (2006), Maciel (2017). Kristeva circunscreve a obra de Bakhtin dentro do estruturalismo, ainda que lhe atribua certa dinamização 
do estruturalismo, reduzindo sua teoria ao texto e ao aspecto funcional da personagem, enquanto o próprio Bakhtin dá ênfase ao discurso, à enunciação, e destacadamente ao processo de enunciação e à personagem não como função, mas como sujeito consciente de seu discurso e especialmente como consciência complexa, interpelada, móvel, fraccionada e movente em fissuras. Além disso, Kristeva apela para o papel do significado, termo fechado e que encerra conteúdos, enquanto Bakhtin prefere trabalhar com o sentido, por ser mais responsivo e dialógico e por permitir a compreensão da relação que a literatura estabelece não somente com outros textos - o que seria confundir dialogismo com intertextualidade - mas com o mundo e com a cultura que estão no texto e que certa forma o fazem.

A leitura direta de um clássico da teoria (termo polêmico, eu sei), como é o caso de Bakhtin, coloca-nos diante de um amplo campo teórico, incluindo a abordagem linguístico-discursiva, a teoria da literatura, a filosofia, a teologia, a semiótica da cultura, o confronto com a psicanálise. Entrar nos textos bakhtinianos é ser desafiado por um vasto campo de confrontos teóricos e de associações teóricas surpreendentes, o que indica que o dialogismo não é somente um conceito operacional para ler certos dados da cultura, mas uma forma de pesquisar, um estilo de pesquisa. Para Bakhtin, dialogismo não é somente um referencial teórico para que instrumentalmente a eficácia da interpretação esteja garantida. Dialogismo é o processo da pesquisa, é a forma como a pesquisa se constitui, como o olhar do pesquisador se move na busca de quadros compreensivos complexos. A pesquisa se torna assim extensão da vida, agora tomada em campos complexos de reflexão e escrita.

Em grande parte essa forma dialógica de pesquisar se tornou possível porque o próprio "objeto" da teoria desencadeou a sofisticação conceitual. A literatura de Dostoiévski, ao inaugurar o romance polifônico, oferecia as bases mais importantes para a formulação do conceito (Todorov chegou a declarar que Dostoiévski foi responsável pela polifonia, Bakhtin a transformou em conceito). A literatura emerge na teoria de Bakhtin não somente como o locus da investigação a 
partir de quadros teóricos pré-definidos, mas como lugar hermenêutico privilegiado para a compreensão das enunciações, das formas de vida, dos arranjos da cultura, enfim, para o dialogismo como concepção do mundo. A literatura pode mudar ou fomentar teorias? Parece ser o caso na obra teórica de Bakhtin.

Tomo, portanto, o conceito de dialogismo como teoria ampla e confronto com teorias do texto e da cultura. O primeiro aspecto a ser destacado é o alcance da teoria proposta de Bakhtin, vinculada não somente ao texto, mas à vida em suas diferentes performances, desde o cotidiano à literatura, à crítica ao teorismo totalitário, incluindo a crítica à linguística e ao marxismo enquanto filosofia. Entendamos, porém, a crítica em Bakhtin dentro do princípio do dialogismo, nunca como mero afã de superação. Em especial, Bakhtin realça a crítica à semiótica, por ela centrar na questão do código e obscurecer a força do contexto - por vezes, Bakhtin se refere ao totalitarismo semiótico de algumas interpretações -, e à dialética, por significar a abstração do diálogo ou ter se tornado um produto abstrato do diálogo. "Pegue um diálogo e remova as vozes (a divisão de vozes), remova as entonações (emocionais e individualizadoras), extraia conceitos e juízos abstratos de palavras e respostas vivas, enfie tudo numa consciência abstrata - eis como se obtém a dialética” (BAKHTIN, 1986b, p. 147). A dialética destrói o dialógico do diálogo. Também a semiótica pode funcionar assim, retirando a vida da linguagem e da cultura. Para Bakhtin, semiótica e dialética são instrumentos de análise de aspectos secundários da constituição do texto e da performance da vida, e o dialogismo centra sua interpretação nas dinâmicas constitutivas do texto e da vida, sem recorrer a teorismos fechados e a sistemas que encerram vida e texto em palavras finalizadoras ou monológicas.

É possível indicar aqui uma convergência entre uma teoria da literatura com uma filosofia da cultura, pelo fato de Bakhtin se ocupar constantemente com os dados extralinguísticos, ainda que estes dados sejam configurados no discurso, na enunciação do texto, mas nunca reduzidos a este. Aliás, é importante salientar a busca de Bakhtin em trabalhar com aquilo que ele mesmo chamou de Metalinguística, que seria uma disciplina nas fronteiras da linguística, da filosofia, 
da antropologia, da teologia e dos estudos literários, capaz de interpretar formas de pensar e agir sem as monocausalidades das teorias de sua época.

Na crítica que Bakhtin faz aos monologismos, ele destaca o dogmatismo e o relativismo, o primeiro, por tentar interditar o diálogo a partir de uma visão causalista ou normativa sobre a vida, e o relativismo, por obstaculizar qualquer possibilidade de posicionamento, já que nada importa e tudo vale.

A vastidão teórica e temática não confunde, porém, o leitor atento. O conceito de dialogismo procede de uma complexa reflexão teórica, mas não se apresenta como algo vago, diluído em fragmentos de teoria. Dialogismo é o conceito para as relações dialógicas que Bakhtin constata nos diferentes campos da vida, apontando para o acontecimento da linguagem como

[...] relações de sentido que se estabelecem entre enunciados produzidos na interação verbal. Nesse sentido, o conceito de dialogismo sustenta-se na noção de vozes que se enfrentam em um mesmo enunciado e que representam os diferentes elementos históricos, sociais e linguísticos que atravessam a enunciação. (ZOPPI-FONTANA, 2005, p. 111).

Mesmo essa constatação não dá conta do conceito bakhtiniano como fundamental para interpretar a cultura, porque a cultura tem que ser interpretada como bagunça, caos, confusão e abertura.

O que constitui o mundo, o que estabelece os critérios para o funcionamento do mundo em sua cotidianidade? Para Bakhtin, unidade, organização, sistemas são esforços, são projetos, são tentativas de sistematização, mas o mundo é, antes de tudo, bagunça, confusão e abertura. Esforçamo-nos para organizar o mundo, mas ele continua a funcionar com aberturas permanentes. Suas redes de diálogo não se restringem a comandos de códigos e sistemas pré-estabelecidos. A vida, como diria Riobaldo em Grande Sertão: Veredas, é por demais esponjosa. Como diz o próprio Bakhtin: "Ainda não aconteceu nada de conclusivo no mundo, a última palavra do mundo e sobre o mundo ainda não foi dita, o mundo é aberto e livre, tudo ainda está no futuro e sempre há de estar no futuro.” Isto se dá em torno do que Bakhtin chama de forças centrífugas (não oficiais) e centrípetas (oficiais), sendo as 
primeiras as responsáveis pelas práticas bagunçadas da vida e as centrípetas as formas de organização das quais nos valemos para tentar ordenar o mundo.

Sua concepção de história evita tanto o causalismo quanto os ordenamentos das significações de esquemas já traçados, pois ambos tiram o devir da história, pois o mundo em seu devir agrega e desagrega e a não-finalizabilidade, conceito tão importante em Bakhtin, caracteriza o que seria o todo do processo histórico e as partes particulares igualmente.

Bakhtin não deixa de reconhecer as forças monologizantes de certos esforços sistemáticos e teóricos em finalizar, encerrar a discussão, oferecer a "última" palavra sobre um tema, uma ideia, uma experiência. Bakhtin ilustra esta tentativa monologizante na filosofia de Platão, por tentar transformar os diálogos em formas de catecismo em torno da verdade, quando inicialmente eles eram buscas dialógicas pela verdade, quase sempre tendo a aporia como conclusão. O pensamento de alguém pode iniciar de forma dialógica e em seu desenvolvimento tentar organizar e fechar um processo. A partir daí a verdade se confunde com regra e modelo e deixa de ser inventividade (poiésis em fluxo) e eventividade (marcada pela situação e possibilidades do dizer e agir).

Outro aspecto fundamental na elaboração dos conceitos bakhtinianos é o papel atribuído ao outro. "Toda a parte verbal de nosso comportamento (quer se trate de linguagem exterior ou interior) não pode, em nenhum caso, ser atribuída a um sujeito individual considerado isoladamente" (BAKHTIN, 2007, p. 182). Entendamos bem a irredutibilidade do outro dentro de um quadro social e cultural mais amplo na teoria de Bakhtin, no confronto que ele estabelece com interpretações chamadas por ele de burguesas, assim como ela faz em seu pequeno ensaio sobre o freudismo. O outro nos constitui por pertencermos a relações sóciohistóricas complexas e contínuas. Não há como escapar das alteridades que a história concreta em que vivemos nos descortina. E quando evitamos alteridades específicas, é porque elas já passaram a fazer parte de nossa trajetória. O individualismo "burguês" é um equívoco fundacional da filosofia moderna, segundo a compreensão da Bakhtin. 
O princípio dialógico se articula em torno da natureza radicalmente sociocultural do existir, por seu caráter intersubjetivo. O segundo aspecto a ser considerado é o de que o signo é, por natureza, para agir, o que se explica pelo fato de vivermos nestes entrelaçamentos intersubjetivos permanentes. Daí decorre que o sujeito é feito do que não é, desse processo de descontinuidade em que se encontra, nesse descolamento das "superfícies discursivas". O discurso que o sujeito produz - lugar por excelência para sua compreensão - é uma propriedade de vozes, um permanente estado dialógico com o outro, que existe amando, odiando, sendo indiferente, irritando, enfim, nos colocando na trajetória deslocada, descontínua, ainda que muito da trajetória evidencie buscas de organizações, controles, domínios, seguranças e quietudes. O ser humano acede à autenticidade de sua voz nesse jogo do "nós" permanente em que se encontra.

Por fim, um aspecto sempre a ser considerado é a relação entre dialogismo e polifonia, aí não temos como evitar o papel da literatura de Dostoiévski para a teoria da cultura e do texto de Bakhtin. É neste contexto das inquietações de Bakhtin com tantas correntes do pensamento que ele destacará o papel de Dostoiévski, cuja obra se tornou objeto principal da sua crítica literária, mas também de sua filosofia da vida e de sua teoria da cultura. Em Dostoiévski, Bakhtin encontra um suporte fundamental para a revisão que ele mesmo empreende do conhecimento. De certa forma, a literatura obriga a teoria a rever seus pressupostos. É na obra de Dostoiévski que encontraremos os exemplos do verdadeiro dialogismo, como unidade de múltiplas vozes, cujas conversações são não-finalizadoras, tendo a polifonia como característica recorrente. A obra de Dostoiévski inaugura o romance polifônico e coloca a consciência das personagens num diálogo constante com as vozes das outras. "A multiplicidade de vozes e consciências independentes e imiscíveis e a autêntica polifonia de vozes plenivalentes constituem, de fato, a peculiaridade fundamental dos romances de Dostoiévski." (BAKHTIN, 2011, p. 4). Aqui é preciso indicar nuanças e matizes. Apesar da proximidade, não confundamos simplesmente dialogismo - teoria da cultura e da linguagem - e polifonia - teoria das personagens e de seus protagonismos na narrativa literária. Certo é que o embaralhamento das vozes no 
romance, o fato de serem constantemente imiscíveis, a plenivalência das personagens, negando a ideia de personagens centrais e secundárias, é uma das bases importantes do dialogismo, mas com certeza não abarca as muitas nuanças desse conceito bakhtiniano.

Bakhtin continuará com esta perspectiva ao abordar o tema do riso e do carnaval na obra de Rabelais, algo que aponta para a outra verdade diante de qualquer verdade oficial. Há sempre o outro dizer, uma paródia a ser contada a respeito do que é considerado normativo e legal, mas são os estudos sobre Dostoiévski que significarão uma guinada importante no pensamento de Bakhtin. Algumas citações indicam isso:

As relações dialógicas são um fenômeno muito mais amplo do que as meras réplicas de um diálogo apresentadas composicionalmente no texto; são um fenômeno quase universal, a permear todo o discurso humano e todas as relações e manifestações da vida humana - em geral, tudo quanto tem sentido e significação. (BAKHTIN, 2011, p. 40)

Ser meio para outro, e através do outro para si mesmo. Uma pessoa não tem território interno soberano, está sempre e totalmente na fronteira; olhando para dentro de si mesma, ela olha nos olhos do outro com os olhos do outro. (BAKHTIN, 2011, p. 287).

Esse processo dialógico se espraia cada vez mais em diferentes âmbitos da cultura, extrapolando uma teoria do texto e alcançando a teoria da linguagem e da cultura.

De fato, qualquer discurso concreto [...] está entrelaçado com pensamentos, pontos de vista, valores estranhos, juízos e acentos compartilhados. A palavra, dirigida para o seu objeto, entra num ambiente dialogicamente agitado e tenso de palavras, juízos de valor e acentos estranhos, urde dentro e fora de inter-relações complexas, funde-se com algumas, afasta-se de outras e cruza-se ainda com um terceiro grupo. (BAKHTIN, 2010, p. 276).

Cada cultura tem significados que ela própria desconhece, não porque o estudioso detivesse, com seu sistema, muitas vezes produtor de destinos já conhecidos, a verdadeira compreensão, mas porque essa teia de significados é um universo que passa por muitas trapaças e associações. "Se uma resposta não suscita uma nova pergunta, está fora do diálogo.” (Para uma metodologia das ciências humanas, 168). O ouvinte (real ou imaginado) molda o enunciado desde o 
princípio. Toda a discussão que Bakhtin trava sobre a linguagem, em sua crítica à linguística, estilística e poética de seu contexto, é a opção por uma disciplina que supera a todas elas: a metalinguística. Cada linguagem reflete um modo assistemático particular de agregar e aglutinar as forças históricas e sociais contingentes que a produziram. Por isso, em sua crítica à linguística, para Bakhtin, qualquer mudança linguística nunca é sistêmica, mas desordenada, produzida por eventos imprevisíveis da atividade cotidiana. Além disso, ela não resulta de forças puramente abstratas (desequilíbrios sistêmicos), mas de ações de pessoas reais em respostas às suas vidas diárias. Daí a questão ética ser fundamental em Bakhtin. A mudança sempre se gera na vida concreta das pessoas, não em sistemas abstraídos da complexidade da vida. As palavras e as formas existem na cultura, na vida, no mundo social não como cadáveres nus, mas como impulsos vivos, com memória e atividade. Bakhtin foca na criação, não simplesmente na obra criada, já-pronta:

Um objeto é já-pronto, os meios linguísticos para a sua descrição são jáprontos, o próprio artista é já-pronto e sua visão do mundo é já-pronta. $\mathrm{E}$ aqui com meios já-prontos, à luz de uma visão do mundo já-pronta, o poeta já-pronto reflete um objeto já-pronto. Mas na verdade o objeto é criado no processo da criatividade, como o são o próprio poeta, sua visão do mundo e seus meios de expressão. (BAKHTIN, 1986c, p. 120).

Não que ele desconheça ou relativize o passado como coisa-dada.

É impossível mudar o lado factual, o lado-coisa do passado, porém o lado significativo, expressivo, pode ser mudado, por ser não-finalizado e não coincidir consigo mesmo (é livre). O papel da memória nessa transformação eterna do passado. A cognição/compreensão do passado na sua finalização-aberta, na sua não-coincidência consigo mesma. (BAKHTIN, 1986c, p. 132).

As buscas de minha própria palavra são na verdade buscas de uma palavra que não é minha, de uma palavra que é mais do que eu próprio; trata-se de uma luta para renunciar às minhas próprias palavras, com as quais nada de essencial pode ser dito. [...] Essas buscas levaram Dostoiévski à criação do romance polifônico. (BAKHTIN, 1986b, p. 149).

Resumindo: o dialogismo e a não-finalizibilidade constituem permanente, criativo, conflitivo, incomodo hibridismo, tão bem articulado em finalidades estéticas nos estudos sobre a polifonia nos romances de Dostoiévski. Dialogismo é, portanto, tanto cultural e "inconsciente" - termo complicado para a teoria de 
Bakhtin, que ressaltou muito mais o dilema da consciência - como parte de um projeto estético.

As coisas estão, portanto, sempre inter-relacionadas em Bakhtin, teoria do eu, crítica às ciências de seu tempo, desenvolvimento de um universo conceitual voltado para o dialogismo e a polifonia, tudo está relacionado na teoria bakhtiniana da cultura, e tanto esse procedimento dialógico de pesquisa quanto alguns dos resultados aqui sumariamente apresentados podem ser de interesse ao estudo das linguagens da religião.

\section{Linguagens da religião: dialógicas, não-finalizáveis e polifônicas}

A religião move-se em campos vastos e complexos de arrumações discursivas e entrecruzamentos simbólicos e éticos. Não há limite para os processos bricolares, as transversalidades podem ser surpreendentes e as práticas podem apontar para os vários pertencimentos dos sujeitos e fazeres culturais, destituindo a seriedade de estudos de religião que tentem reduzi-la a qualquer ser essencializado, tentando apresentar um ordenamento definitivo que a religião em suas diferentes linguagens desconhece. A religião não tem limites em suas possibilidades de tornar-se. Os textos da religião nunca são os mesmos e nem podem ser, por conta da complexidade cultural a que estão submetidos e aos muitos humores e interesses dos leitores em seus devires. Os ritos da religião nunca são meras monotonias, porque dependem sempre dos corpos com suas inscrições, seus afetos e memórias. A ética da religião nunca é uniforme ou de manual, porque ela pode gerar tanto os gestos solidários e poéticos quanto a estupidez e a violência. A narrativa da religião nunca é linearidade discursiva, antes é a reunião das entonações, da imiscibilidade das vozes, das contradições das ações. Religião não é linguagem domesticável, ela é, ao mesmo tempo, reino de quietudes e sossego, mas também conflito e rebeldia. Tudo cabe na religião, talvez por isso seja sempre possível de novo instrumentalizá-la e tentar reduzi-la a um único campo de experiências e dizeres, por isso é possível que convivam lado a lado igrejas tradicionais em sua rigidez - cada vez mais em extinção - e as muitas comunidades 
cujos nomes sequer talvez tenhamos condições de saber para nossas sistematizações. Como vida e processo na cultura, as linguagens da religião não podem ser censuradas em qualquer tipo de dever-ser determinado seja pela teologia, seja pelas ciências sociais. Não que determinados aspectos da religião não possam ser canalizados, por exemplo, em prol de uma doutrinação teológica para a performance ética de um grupo. A questão não é essa. O que não deve ser confundido e pressuposto é que, quando isso é feito, estejamos ainda em condições de reduzir a religião a essa prática ou a essa tentativa ética de fazer algo no mundo. As palavras da religião são de múltiplas associações. Os ritos da religião têm constituições confusas. O simbolismo da religião é aberto. A ética da religião é tênue, porque nela encontramos tanto a possibilidade de, por exemplo, lutar pelos oprimidos quanto defender o direito do opressor. A história, essa professora fracassada que nada nos ensinou, está cheia desses “extremos” numa única religião. Nesse sentido, a religião pode ser, sim, vontade de poder (quem não a tem?), como atestou uma sociologia em tempos recentes, mas reduzi-la a isso é um descalabro teórico e um equívoco conceitual. O que caracteriza mais agudamente as linguagens da religião? Sua intensidade incomparável, suas muitas rotas de colisão e encontros. A religião é a infinitude das possibilidades humanas em suas narrativas, celebrações e ações.

Os conceitos bakhtinianos apontam para consequências que considero fundamentais no estudo da religião: lidamos com linguagens que são infinitas, no sentido de múltiplas, diversas, inesperadas, e que não deveriam ser tratadas com conceitos reducionistas. Reduzir a religião cristã, por exemplo, a um programa de lutas sociais, assim como fez a teologia da libertação, é praticar assepsia doutrinária de uma realidade muito complexa. Por outro, reduzir a religião, enquanto experiência e possibilidade de criar sentido ao mundo, a um déficit antropológico, é outra violência a que nos acostumamos em algumas ciências da religião.

Pressupondo o que deveria ser o óbvio de nossas constatações, seria importante avançar em estudos que destinassem contribuições de uma teologia 
como a Teologia da Libertação ao estudo das religiões ao seu lugar devido: uma tentativa de estabelecer um limite à diversidade que é a multifacetada presença dos cristianismos em nosso continente, a pergunta é se essa tentativa deve interessar ao estudo da religião, sou da opinião que não mais. Assim também deveríamos destinar alguns estudos sociológicos da religião ao seu devido lugar: tentativa de reificar o que a modernidade já apontava em seus primórdios e em seu desenvolvimento: a religião se origina em algum déficit antropológico e cultural. $\mathrm{Ou}$ rompemos com essas perspectivas ou sempre retornaremos às instrumentalizações já conhecidas e produtoras de escolas, discípulos e filiações. É preciso reconhecer as monstruosidades, inventividades e bricolagens que a religião faz todos os dias para que ela ocupe novamente seu lugar: a linguagem infinita mais radical que conhecemos. Para não confundir o leitor e aos interessados em defender a religião sempre como fantasia, festa, estética, beleza: religião é isso e aquilo, é paz e violência, é luta, tormento, mas também distância e mística ilhada. O fascinante e o difícil é justamente essa realidade da religião, que abarca horizontes, práticas e valores que não são contemplados por nenhuma, e ressalte-se nenhuma, teoria reducionista, ou no dizer de Bakhtin, nenhum teorismo dogmático ou totalitarismo semiótico.

Na contravenção da modernidade, a religião não é casarão desabitado de sentidos e de possiblidades de significação. Exatamente o contrário: religião é casarão habitado por muitos, e nesse amálgama de coisas e experiências, narrativas e iconografia, personagens e deuses em movimento e fluxo, a pluralidade, não a uniformidade, a não-finalizibilidade, não o encerramento ideológico-teórico, o dialogismo, não a monologia e a repetição, deveriam ser os pressupostos nos estudos da religião, e isso também deveria ter consequência para os resultados a que chegamos, porque a redução é sempre uma violência ao objeto que escolhemos.

Ora, se a religião vive nesse fluxo contínuo de imbricações, como deveríamos entender as linguagens da religião? Como poderíamos chegar a resultados confiáveis em nossos estudos? Se está tudo aberto, nada é finalizável e o processo dialógico caracteriza e move o cotidiano da religião - linguagem de singular 
infinitude -, como podemos ainda chegar a resultados das pesquisas? Essa é uma questão que talvez seja necessária, mas a própria questão precisa ser problematizada. Por um lado, parece que nos acostumamos às tipologias identitárias reducionistas das ciências de tal forma que deixamos de considerar quão frágeis elas são para lidar com a complexidade de nosso campo de estudo. $\mathrm{O}$ problema não é que uma teoria como a de Bakhtin nos coloque num processo tão fluido em torno da religião que obstaculizaria qualquer resultado mais consistente, antes o problema reside em nossa cultura científica de garantir o resultado a partir de uma redução qualquer feita a priori. O dialogismo e a não-finalizibilidade das muitas bricolagens culturais-religiosas não deveriam nos inibir de buscar os resultados, esses conceitos e postulados só exigem de nós que saiamos de nossa zona de conforto conceitual e nos aventuremos em perspectivar a religião de tal forma a considerar seus aspectos surpreendentes, suas inventividades incômodas e suas eventividades singulares. Talvez, quando sairmos radicalmente de nossas zonas de conforto, constatemos que alguns conceitos tão firmados em nossos redutos acadêmicos passem a ser considerados mais como exercício doutrinário de controle do que prática ousada de construir pensamento desafiador.

Será que parte do que fizemos nos estudos da religião no Brasil não é um longo, mas monótono percurso de destrato da religião em sua complexidade e em seus muitos dialogismos? Talvez a ideia de que a religião cristã é uma religião dos oprimidos e que serve para organizar os oprimidos, assim como a ideia de que religião seja reduzível a uma função social que ela possa assumir ou que, segundo alguns teóricos em nosso contexto, assume de forma frequente, talvez essa ideia de pensar a religião nesses termos só revele quão estreita e autoritária é nossa visão de religião, porque nos muitos (a) fazeres cotidianos, a religião transborda essas circunscrições e continua a operar de forma mais transversal e desrespeitosa do que nossa asséptica ciência quer reconhecer e permitir.

Os conceitos bakhtinianos talvez nos ajudem a reconhecer na religião um material ainda bruto e rude o bastante que exija de nós uma ciência menos éticodoutrinária, menos tipológico-funcionalista, menos moderna, pelo excesso de 
discriminação e preconceito que a modernidade cria sobre a religião. Talvez aí reconheçamos que o dialogismo e a não-finalizibilidade apontem para as muitas expressões fraturadas das diversas sensibilidades que se agrupam e constituem nas linguagens da religião, assumindo, algumas vezes, formas inéditas. Para lembrar Glissant, um leitor de Bakhtin: "Todas as possibilidades, todas as contradições estão inscritas no diverso do mundo.” (GLISSANT, 2002, p.27), lembrando que a diversidade não é simplesmente o "melting-pot", mas os pontos de encontro das diferenças e dos antagonismos, com resultados sempre imprevisíveis. Se o caosmundo é o mundo da religião, ainda que a religião apresente sólidos parâmetros de tentativa de ordenação do mundo, mas o caos-mundo é seu lugar de origem e construção narrativa, não podemos esquecer que teríamos que pensar outras poéticas para lidar com essa realidade. "As poéticas do caos não podem ser pensadas com abnegação a parâmetros formais” (Glissant, 2002, p. 81). Se o caosmundo é o mundo da religião, então teríamos que pensar as subjetivações religiosas a partir das estéticas das relações, bricolagens e criações. O caráter "errático" da religião nos interessaria muito mais do que os ordenamentos sistematizados e monologizantes. Se o dialogismo é uma possibilidade de aproximação da religião, então suas linguagens não poderiam estar a serviço de uma ciência que reivindique para si o juízo restritivo e reducionista da religião. Praticamos tal ciência?

\section{Conclusão: questão aberta}

A religião em suas infinitudes constitui, muitas vezes, um ordenamento do mundo que pode "salvar” ou vigiar e controlar. Tal ordenamento não se dá sem uma dose significativa de autoritarismo. Seria possível imaginar o fim do aspecto dialógico da religião por conta de um monologismo autoritário e reducionista que encontramos em algumas de suas práticas? Em outras palavras: A religião pode ser tornar um monologismo tão perverso que encerraria qualquer possibilidade de dialogismo? 
Sem responder diretamente à questão - ela é aberta -, lembro ao leitor de que a teoria da Bakhtin surge exatamente num contexto marcado pelo excesso de forças autoritárias e totalitárias. Justamente aí Bakhtin fala de dialogismo, polifonia e não-finalizibilidade. Teorias podem ser resistências criativas e indicar que processos criativos vivem nos subterrâneos de uma história que se cansa do excesso de controle, repetição e formalidade. Há sempre algo à espreita no processo da cultura que quebra a linearidade do discurso.

\section{REFERÊNCIAS}

BAKHTIN, M. M. Problemas da poética de Dostoiévski. Tradução Paulo Bezerra. 5 . ed. Rio de Janeiro: Forense Universitária, 2011.

BAKHTIN, M. M. Os gêneros do discurso. In: BAKHTIN, M. M. Estética da criação verbal. Tradução Paulo Bezerra. 4. ed. São Paulo: Martins Fontes, 2003. p. 261-306.

BAKHTIN, M. M. Towards a methodology of the human sciences. In: EMERSON, Caryl; HOLQUIST, Michael (Ed.). Speech genres and other late essays. Austin: University of Texas Press, 1986a. p. 159-172.

BAKHTIN, M. M. From notes Made in 70-71. In: EMERSON, Caryl; HOLQUIST, Michael (Ed.). Speech genres and other late essays. Austin: University of Texas Press, $1986 \mathrm{~b}$.

BAKHTIN, M. M. The Problem of the text in linguistics, philology and the human sciences: an experimente in philosophical analysis. In: EMERSON, Caryl; HOLQUIST, Michael (Ed.). Speech genres and other late essays. Austin: University of Texas Press, 1986c. p. 118-138.

BAKHTIN, M. M. O freudismo: um esboço crítico. São Paulo: Perspectiva, 2007.

BAKHTIN, M. M. A cultura popular na Idade Média e no Renascimento. O contexto de François Rabelais. São Paulo: Hucitec, 2010.

BAKHTIN, M. M. Metodologia das ciências humanas. In: BAKHTIN, M. M. Estética da criação verbal. São Paulo: Martins Fontes, 2003. p. 393-410.

BAKHTIN, M. M; VOLOCHÍNOV, V. N. Marxismo e filosofia da linguagem. São Paulo: Hucitec, 2009.

BAKHTIN, M. M. O discurso no romance. In: BAKHTIN, M. M. Questões de literatura e de estética. São Paulo: Hucitec, 2010. p. 71-210. 
BEZERRA, P. Prefácio: uma obra à prova do tempo. In: BAKHTIN, M. M. Problemas da poética de Dostoiévski. Tradução Paulo Bezerra. 5. ed. Rio de Janeiro: Forense Universitária, 2011.

BRAIT, B. (Org.). Bakhtin: outros conceitos-chave. São Paulo: Contexto, 2006.

BRAIT, B. (Org.). Bakhtin: dialogismo e construção do sentido. Campinas: Editora da Unicamp, 2005.

GLISSANT, Édouard. Introducción a una poética de lo diverso. Barcelona: Ediciones del Bronce, 2002.

GUATTARI, Felix. Caosmose: um novo paradigma estético. Rio de Janeiro: Editora 34, 1992.

KRISTEVA, J. Introdução à sem análise. 3. ed. revista e aumentada. São Paulo: Perspectiva, 2012.

MACIEL, Lucas Vinício de Carvalho. A (in) distinção entre dialogismo e intertextualidade. Linguagem em (dis) curso - LemD, Tubarão, SC, v. 17, n. 1, p. 137-151, jan./abr. 2017.

NOGUEIRA, Paulo A.S. Religião e linguagem: Proposta de articulação de um campo complexo. Horizonte, p. 240-261, abr./jun. 2016.

PONZIO, Augusto. A revolução bakhtiniana. São Paulo: Editorial Contexto, 2008.

ZOPPI-FONTANA, Mónica Graciela. O outro da personagem: enunciação, exterioridade e discurso. In: BRAIT, Beth (Org.). Bakhtin: dialogismo e construção do sentido. Campinas: Editora da UNICAMP, 2005, p.108-118. 